\title{
Molecular characterization of crude enzymatic extract from algerian camel abomasum (Camelus dromedarius)
}

\author{
Souad Isselnane ${ }^{1 *}$, Saliha Boudjenah-Haroun², Abdelwahab Nouaniं ${ }^{3}$, Saliha SI Ahmed-Zennia', Belaid Bouazza', \\ Benalia Yabrir ${ }^{4}$ and Abderrahmane Mati ${ }^{1}$ \\ ${ }^{1}$ Laboratoire de Recherche de Biochimie Analytique et Biotechnologies (LABAB), Université Mouloud Mammeri de Tizi Ouzou, 15000 , \\ Algérie; '2Université Ouargla, Faculté des Sciences de la Nature et de la Vie, Laboratoire de Recherche sur la Phoeniciculture, Ouargla 30000, \\ Algérie; ${ }^{3}$ Laboratoire de Technologie Alimentaire, Université M'Hamed Bouguera, Boumerdes, 35 000, Algérie; ${ }^{4}$ Laboratoire d'exploration et \\ Valorisation des Ecosystèmes Steppiques, Université de Djelfa, Algérie
}

\section{A B S TR A C T}

\begin{abstract}
Camel milk cannot be coagulated with bovine chymosin, most likely due to major variations between the primary $\mathrm{k}$ casein structures of the two species. Recently we have shown that the crude gastric extracts (CGE) from adults' dromedaries provide satisfactory milk clotting activity and limited proteolytic activity towards the camel milk. In the present study, we have isolated and characterized the CGE from dromedary abomasum. The CGE was separated and purified by DEAE-Cellulose column chromatography and Sephacryl S200 gel filtration. From various collected fractions, we characterized two fractions (F3 and F5) presenting a milk clotting activity and were eluted at $0.1 \mathrm{M}$ and $0.45 \mathrm{M} \mathrm{NaCl}$ respectively. Interestingly, the $\mathrm{F} 5$ fraction had the highest milk clotting activity. The purified enzyme was resolved as a single protein band on SDS-PAGE with a molecular weight estimated about $38 \mathrm{kDa}$ which was not affected by the addition of $\beta$-mercaptoethanol. In native PAGE, the enzyme migrated as a single band having a high intensity with similar electophoretic mobility to that of porcine pepsin. Using two dimensional electrophoresis, we found that the band obtained from the native-PAGE was concentrated on a single spot, quite intense.
\end{abstract}

Keywords: Abomasum; Chromatography; Dromedary; Electrophoresis; Mmilk clotting enzyme

\section{INTRODUCTION}

By its morphological, physiological and behavioral characteristics, the camel can produce and feed in the harshest environmental conditions. Thus the camel remains a farm animal best suited to the desert.

Among numerous camel productions, the milk is a noble product that has a high nutritional value and great balance in basic nutrients (carbohydrates, lipids and proteins). It is also rich in vitamin $C$ and contains traces of certain proteins and enzymes (lysozyme, lactoperoxidase, lactoferrin) which form a powerful protective system with intense antimicrobial activity. The therapeutic properties and nutritional value of camel milk naturally advocate for the development and extension of camel breeding dairy.

Nevertheless, compared to other milk species, the clotting of camel milk for cheese making is reputed for being a difficult process (Ramet, 1989). The action of rennet on camel milk leads to coagulation in the form of flocks with no firm coagulum (Farah and Bachmann, 1987; Bornaz et al., 2009). This behavior is mainly attributed to the low content in kappa casein $3.5 \%$ in camel milk versus $13 \%$ in bovine milk) (Mehaia et al., 1995; Kappeler et al., 1998; Chaoui-Kherouatou and Attia, 2008) and the larger size of casein micelles (camel milk up to $600 \mathrm{~nm}$ versus $160 \mathrm{~nm}$ in bovine milk) (Farah and Ruegg, 1989; Farah, 1993). Acid coagulation is weak. However, rich in antibacterial products, camel milk tends to inhibit natural lactic fermentation by acidification (Ramet, 2003). However, recently, a specific recombinant camel chymosin from Hansen company (chy-max-M (C) has been proposed on the market and give good results for cheese making (Konuspayeva et al., 2014)

In order to improve the ability of camel milk to be coagulated, several studies demonstrated that coagulation of camel milk was achieved after mixing it with goat, sheep, or buffalo milk (Rao et al., 1970). Others reported that camel 
milk could be coagulated if high amounts of calf rennet are added (Chapman, 1985).

Several observations suggest that the clotting enzyme from a particular species is more effective with milk of the same species. This was demonstrated in lambs (Herian and Krcal, 1971) and pigs (Foltmann et al., 1981; Houen et al., 1996). Clotting time of camel milk was significantly reduced, when camel calf rennet was used instead of bovine (Wangoh et al., 1993) or buffalo calf rennet (El-Agamy and Kamal, 1998; El-Agamy, 2000). Recently, we have demonstrated that the extract from the adult camel abomasum has provided good milk clotting activity and limited proteolytic activity toward camel milk (Boudjenah-Haroun et al., 2011; Boudjenah-Haroun et al., 2012).

In this study, we sought to analyze and characterize the crude enzyme extract from adult Algerian camel by using a combination of chromatographic and electrophoretic techniques.

\section{MATERIALS AND METHODS}

\section{Extraction of enzyme}

The camel abomasal tissues were obtained from camel slaughterhouse of Ouargla, south of Algeria. The third stomach of the camel (Camelus dromedarius) was removed. The abomasums were obtained from suckling, mixed feed and weaned camels. Abomasal tissues were cut out, washed thoroughly with cold water, defatted, and minced into small pieces. The minced tissue was frozen at $-18{ }^{\circ} \mathrm{C}$. The extraction was performed according to the method of Valles and Furet (1977) with minor modifications. The tissue was homogenized with $0.2 \mathrm{M} \mathrm{HCl}$ solution at $42^{\circ} \mathrm{C}$ for 60 minutes. After the filtration of the homogenate, the crude enzyme extract was clarified with $1 \mathrm{M}$ aluminium sulphate solution, $1 \mathrm{M}$ disodium sulphate with continuous stirring for few minutes at $42{ }^{\circ} \mathrm{C}$. After the filtration, a double solution of saturated $\mathrm{NaCl}$ containing $1 \%$ (w/w) of concentrated $\mathrm{HCl}$ was added to the crude extract and the mixture was kept to stand for $60 \mathrm{~min}$, and then centrifuged $(2100 \times \mathrm{g}, 20 \mathrm{~min})$. The precipitate was dissolved in a minimum volume of distilled water. The $\mathrm{pH}$ of the released enzyme extracts was then adjusted to 5.5 with $1 \mathrm{M}$ disodium phosphate solution. The crude extract was dialyzed using a dialysis membrane of $10-\mathrm{kDa}$ cut-off size against distilled water at $4{ }^{\circ} \mathrm{C}$.

The extracts obtained were named CGE S for Crude Gastric Extract from Suckling dromedaries, CGE M from Mixed feed and CGE W from Weaned animals.

\section{Clotting activity}

The milk clotting activity was determined according to Berridge (1945) modified by Collin et al. (1977). Briefly,
$1 \mathrm{~mL}$ of crude extract or fractions was added to $10 \mathrm{ml}$ of Berridge substrate, mixed thoroughly and incubated at $30{ }^{\circ} \mathrm{C}$. The time required for the first appearance of the flakes was recorded. One unit of milk clotting activity was defined as the amount of enzyme required to clot $10 \mathrm{ml}$ of milk in $100 \mathrm{~s}$ at $30^{\circ} \mathrm{C}$.

$\mathrm{RU}=10 \times \mathrm{V} / \mathrm{Tc} \times \mathrm{Q}$

Where:

RU: Rennet Unit

$\mathrm{V}$ : Volume of standard substrate $(\mathrm{mL})$

Q: Volume of CGE (mL)

Tc: Time of clotting (sec).

\section{Protein concentration assay}

The protein concentration of different samples after each purification was determined by the method of Lowry et al. (1951) by measuring the absorbance at $750 \mathrm{~nm}$. The bovine serum albumin was used as a standard.

\section{Enzyme purification}

The purification of the CGE from adults' dromedaries was carried out on a low-pressure chromatography system (BioRad, France), by ion exchange chromatography on DEAECellulose (DE52, Watman, France) and gel filtration using Sephacryl S200 resin. The dialyzed enzyme extract was applied to a column packed with DEAE-Cellulose-52 (10 $\mathrm{x} 1 \mathrm{~cm}$ ) and equilibrated with $0.06 \mathrm{M}$-sodium phosphate buffer, $\mathrm{pH}$ 5.5. The column was then washed with the same equilibration buffer until the absorbance of the eluent at $280 \mathrm{~nm}$ was $<0.05$. The bound proteins were eluted with a linear gradient of $0 \mathrm{M}-1 \mathrm{M} \mathrm{NaCl}$, at room temperature, at a flow rate of $0.5 \mathrm{~mL} \mathrm{~min}^{-1}$, with peristaltic pump and $1.5 \mathrm{~mL}$ fractions were collected (Rothe et al., 1976). The milk clotting activity of individual peak fractions was measured. The absorbance of the fractions was determined at $280 \mathrm{~nm}$ using the LP Data View software. At each step of the purification, the fractions having milk clotting activity were desalted by dialyzing against $0.06 \mathrm{M}$ sodium phosphate buffer ( $\mathrm{pH} 5.5$ ).

For further purification, the fractions showing milk clotting activity were applied to a column $(20 \times 1 \mathrm{~cm})$ of Sephacryl S200 equilibrated and eluted with $0.15 \mathrm{M} \mathrm{NaC} 1$ in 0.06 M-sodium phosphate buffer, $\mathrm{pH} 5.5$ at room temperature. $1.5 \mathrm{~mL}$ fractions were collected at a flow of $0.3 \mathrm{~mL} \mathrm{~min}^{-1}$.

\section{Polyacrylamide gel electrophoresis}

Non-denaturing polyacrylamide gel electrophoresis (Native PAGE) of the crude extract was performed according to Hillier (1976) using 12\% polyacrylamide gel and Tris-glycine buffer, $\mathrm{pH}$ 8.3. Samples $\left(2 \mathrm{mg} \cdot \mathrm{mL}^{-1}\right)$ were dissolved in $75 \mathrm{mM}$ Tris-HCl buffer, $\mathrm{pH} 8.9$, containing $10 \%$ (v/v) glycerol, and 
0.01\% (w/v) bromophenol blue. Sodium dodecyl sulphate PAGE (SDS-PAGE) of the crude extract and the fractions from ion exchange and gel filtration column was performed according to Laemmli (1970). SDS-PAGE was performed by mixing samples with sample buffer, incubated at $100{ }^{\circ} \mathrm{C}$ for 5 min, and loading on to a $17 \%$ slab gel. Molecular weight marker (BioRad) ranging from 17 to $250 \mathrm{kDa}$ was used. The fermentation produced chymosin (CHY-MAX) and pepsin from hog stomach were used as a control. The proteins were stained with Coomassie Brilliant Blue. Silver staining was used to visualize the proteins in fractions presenting milk-clotting activity obtained from ion exchange and gel filtration chromatography.

\section{RESULTS AND DISCUSSION}

\section{Electrophoretic characterization of CGE}

The enzymatic extracts from weaned dromedary abomasums as well as suckling and mixed diet dromedary abomasums were isolated and characterized. The enzyme extracts obtained were analyzed by SDS-PAGE (Fig. 1). The quality and quantity of proteins from the 3 samples were significantly different. Therefore, it is possible to verify the origin of the dromedary abomasums and whether they come from a suckling, mixed diet and weaned camel.

Interestingly, the CGE W profile showed a band at $38 \mathrm{kDa}$ (band A) with higher intensity compared to other CGE extracts. This band is located in the immediate vicinity of the chymosin $(\mathrm{C})$ and pepsin $(\mathrm{P})$ used as a control.

The purification of milk clotting enzyme from adult camel abomasum

Abomasa from adult camels were used for purification. A typical result of purification is summarized in Table 1. Relative specific activity of crude extract in abomasal mucosae of these individuals were 0.127 units $/ \mathrm{mg}$ protein. Five protein peaks were obtained by applying the crude extract to a DEAE-cellulose chromatography (labeled F1 to F5), and only two peaks (F3 and F5) revealed varying degrees of enzyme activities (Fig. 2a). The F3 fraction was eluted at $0.1 \mathrm{M} \mathrm{NaCl}$, while the F5 fraction was eluted at $0.45 \mathrm{M}$. Importantly, F5 fraction showed the highest milk-clotting activity.

Under chromatographic $\mathrm{pH}$ conditions, the $\mathrm{F} 3$ fraction was eluted first. Its binding to the DEAE-cellulose column at

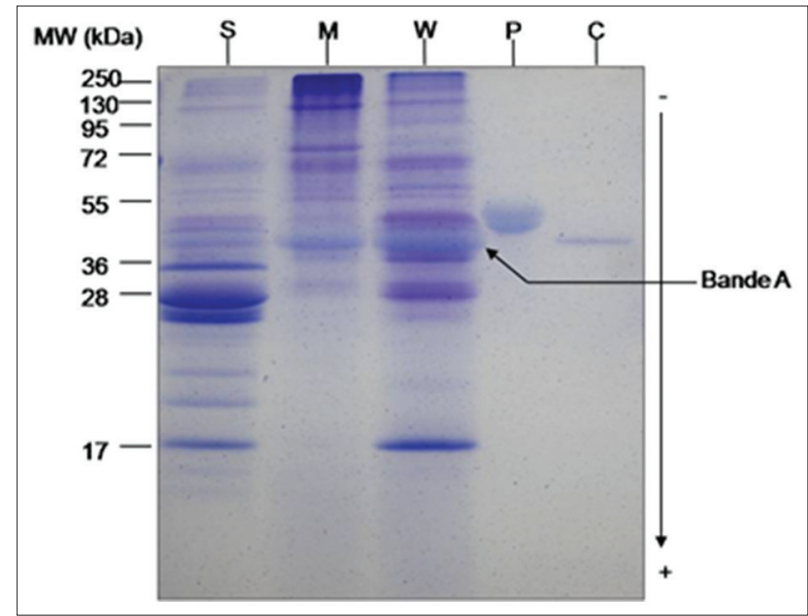

Fig 1. SDS-PAGE (17\%) profile of the crude extract.

S: crude gastric extract from suckling dromedaries (CGE S), M: mixed feed (CGE M), W: Weaned (CGE W), P: porcine pepsin, C: Fermentation produced chymosin (CHY-MAX), MW: Molecular weight.

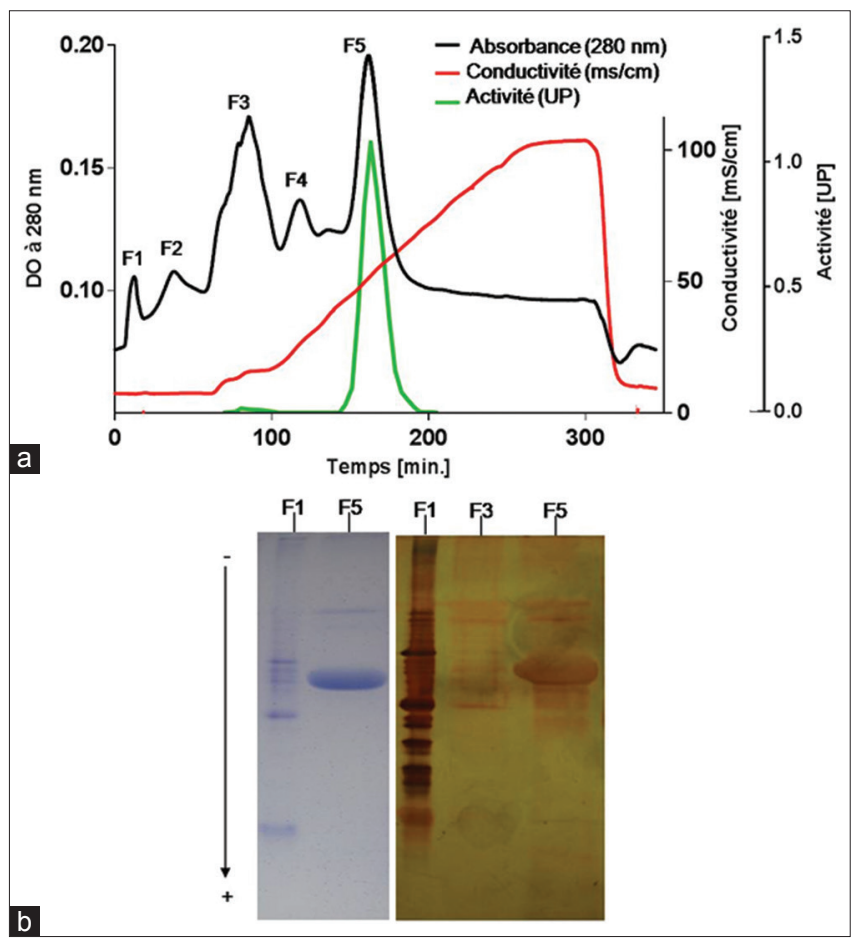

Fig 2. (a) DEAE-cellulose chromatography of the crude extract of adult camel abomasal mucosa on a column $(1 \times 10 \mathrm{~cm})$. The column was equilibrated with $0.06 \mathrm{M}$ sodium phosphate buffer, $\mathrm{pH} 5.5$ and proteins were eluted with a linear gradient of $\mathrm{NaCl}$ in the same buffer. The flow rate was of $0.5 \mathrm{~mL}$ min-1. Fractions of $1.5 \mathrm{ml}$ were collected. (b) SDS-PAGE of the fractions from the first chromatography.

F1 to F5: protein fractions.

Table 1: Purification of camel milk clotting enzyme

\begin{tabular}{lccccc}
\hline $\begin{array}{l}\text { Purification } \\
\text { steps }\end{array}$ & $\begin{array}{c}\text { Total protein } \\
(\mathbf{m g})\end{array}$ & $\begin{array}{c}\text { Total activity } \\
(\mathbf{R U})\end{array}$ & $\begin{array}{c}\text { Specific activity } \\
\text { (RU/mg) }\end{array}$ & $\begin{array}{c}\text { Relative purification } \\
\text { fold }\end{array}$ & $\begin{array}{c}\text { Activity } \\
\text { yield (\%) }\end{array}$ \\
\hline Crude extract & 30.8 & 3.91 & 0.127 & 1.0 & 100 \\
DEAE-cellulose & 1.848 & 0.702 & 0.379 & 3.0 & 17.95 \\
Sephacryl S200 & 0.904 & 0.555 & 0.614 & 4.84 & 14.19 \\
\hline
\end{tabular}

RU: Rennet unit 
$\mathrm{pH} 5.5$ was weak. This confirms that the $\mathrm{p} I$ value of $\mathrm{F} 3$ fraction is greater than the F5 fraction.

In addition, commercial bovine chymosin produced by fermentation (CHY-MAX) and porcine pepsin were used as control. In the same experimental conditions chymosin was eluted at $0.26 \mathrm{M} \mathrm{NaCl}$ while pepsin was eluted at $0.44 \mathrm{M}$ $\mathrm{NaCl}$ (data not shown). Commercial bovine chymosin and porcine pepsin had close binding characteristics to DEAE- cellulose ion-exchange column as that observed for the F3 and F5 fractions, respectively.

Based on our data, it was concluded that the F5 fraction eluted at $0.45 \mathrm{M}$ could correspond to pepsin. Our results were in accordance with those of Abuharfeel and Abuereish (1984) and Al-Mzaien (2007) studies where they achieved the elution of camel pepsin with $0.40-0.54 \mathrm{M}$ obtained by ion exchange chromatography on DEAE cellulose column.

Pepsin from other ruminants is not used for cheese making because of its higher proteolytic activity and low milk clotting activity. However, unlike the pepsin from other ruminants, the CGE from adults' dromedaries, containing pepsin, provide satisfactory milk clotting activity and limited proteolytic activity towards the camel milk (Boudjenah-Haroun et al., 2011; Boudjenah-Haroun et al., 2012). Therefore, the CGE from adults' dromedaries is suitable for improving the coagulation of the camel milk. Furthermore, it has been reported that Pepsin-rich clotting rennet coagulates camel milk well (Ramet, 1985; El-Abassy, 1987; EL-Batawy et al., 1987).

DEAE cellulose chromatography led to a 3.0-fold purification of this enzyme with specific activity of 0.379 rennet unit/mg protein (Table 1). During this experiment, the enzyme was observed to resolve into one component on DEAE-cellulose ion exchange chromatography indicating possible homogeneity (Fig. 2a). However the presence of other zymogens is not excluded as concentration is low to be detected under the experimental conditions. These results are partially in agreement with those from Abuharfeel and Abuereish (1984) and Al-Mzaien (2007) studies where they purified camel pepsin and observed two major peaks corresponding to isozymes of pepsin (pepsin I and II) eluted under different conditions at $0.43 \mathrm{M}$ and $0.54 \mathrm{M}$, respectively. Similarly, others have also reported heterogeneity of pepsin in crude extract in abomasal mucosae of adult animal (Kageyama and Takahashi, 1976; Martin, 1984; Suzuki et al., 1999).

Our study also reveals the presence of a very low milk clotting activity corresponding to the $\mathrm{F} 3$ fraction eluted at 0.1 M (Fig. 2a). Al-Mzaien (2007) reported the presence of low milk clotting activity corresponding to the fraction eluted at $0.24 \mathrm{M} \mathrm{NaCl}$ under different conditions and that would be the chymosin. However, we did not focus on F3 fraction because of its low milk clotting activity.

The homogeneity of the fractions was checked by SDS-PAGE stained with Coomassie Brilliant Blue (CBB) and Silver which was 100 -fold more sensitive than CBB staining. As shown in Fig. $2 \mathrm{~b}$ the electrophoregram implies that the F5 fraction had distinct bands around and below major protein band of $38 \mathrm{kDa}$. Therefore, the partial purification process was not enough and should be improved by using gel filtration chromatography.

The protein of interest (F5 fraction) was concentrated and then subjected to Sephacryl S-200 gel filtration. The elution profile revealed two closely spaced chromatographic peaks corresponding to one major (F'1) and one minor (F'2) fractions (Fig. 3a). These fractions gave a single activity peak which coincides with the major fraction (F'1). As a result, specific activity of 0.614 rennet unit/mg protein was obtained with purification folds of 4.84 (Table 1).

The homogeneity and molecular weight estimation of the active fraction were determined. The purified enzyme was quite homogeneous in nature as shown by the presence of a major protein band representing the enzyme examined

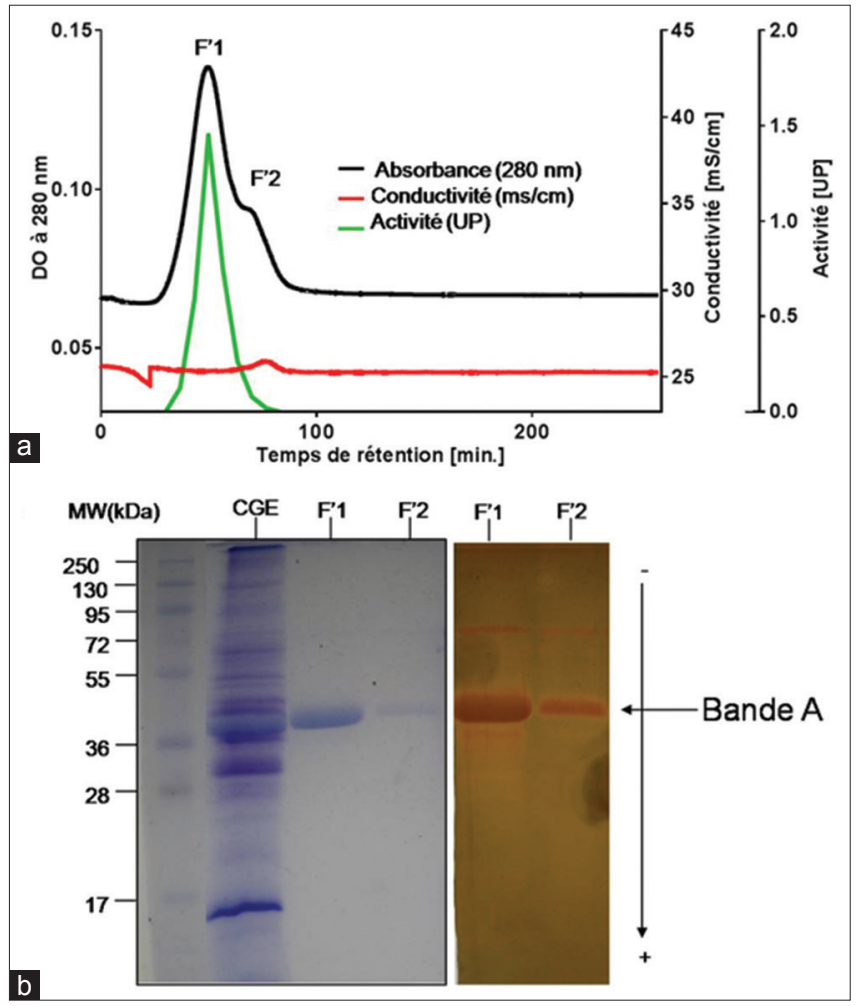

Fig 3. (a) Sephacryl S-200 chromatography of the fraction (F5) with high enzyme activity from the first chromatography DEAE cellulose chromatography. (b) SDS-PAGE of the enzyme purified from the adult crude extract of Camelus dromedarius.

MW: molecular weight, $C G E$ : crude gastric extract, $F^{\prime} 1$ and F'2: protein fractions. 
by SDS-PAGE (Fig. 3b). The two fractions (F'1 and F'2) showed the same single band on SDS-PAGE (Fig. 3b), but they differ from one another in the amount of enzyme they contain. These results suggest that the major part of the enzyme was eluted in fraction corresponding to the F'1 fraction.

The molecular weight of the major band corresponding to the enzyme was estimated to be approximately $38 \mathrm{kDa}$ under reducing conditions which was higher than that of the camel pepsin purified by Abuharfeel and Abuereish (1984) and Al-Mzaien (2007) and also higher than these from cattle (Fox et al., 1977), sheep (Fox et al., 1977), Japanese monkey (Kageyama and Takahashi, 1976), mouse (Esumi et al., 1978) and pigs (Rajagopalan et al., 1966). This difference could be the result of post-translational modifications such as phosphorylation. Additionally, it could be probably due to the diet and breed of the Algerian camels from which the enzyme was extracted.

\section{CGE W electrophoretic profile}

In order to further characterize the crude extract of adult camel abomasum, some additional assays were performed.

Assays carried out at neutral electrophoresis system (Fig. 4) showed that stomach extracts of adult camel exhibited two bands. The band A had similar mobility as porcine pepsin used as control.

The two-dimensional electrophoresis (Fig. 5), combining Native-PAGE in the first dimension and the SDS-PAGE with reducing agent in the second dimension showed that the band A on non-denaturing PAGE was focused into an apparently single spot of high intensity which corresponds to the band A on SDS PAGE allocated to pepsin.

SDS-PAGE with and without reducing agent (Fig. 6) was intended to examine whether some proteins having particular subunits linked specifically by disulfide bonds.

By comparing the crude extract profile with or without $\beta$ mercaptoethanol, we found that electrophoretic mobility of the main bands was similar with the same intensity.

The band A that could match pepsin does not appear to contain disulfide bonds. However, the presence of disulfide bonds intra channels is not excluded. Porcine pepsin contains three intra channels disulfide bonds which were essential for folding, stability, and tertiary structure of the enzyme (Tang et al., 1973). It seems also that the protein corresponding to this band would have a globular monomeric structure. Pepsin is an enzyme of gastric juice mainly found in adults.

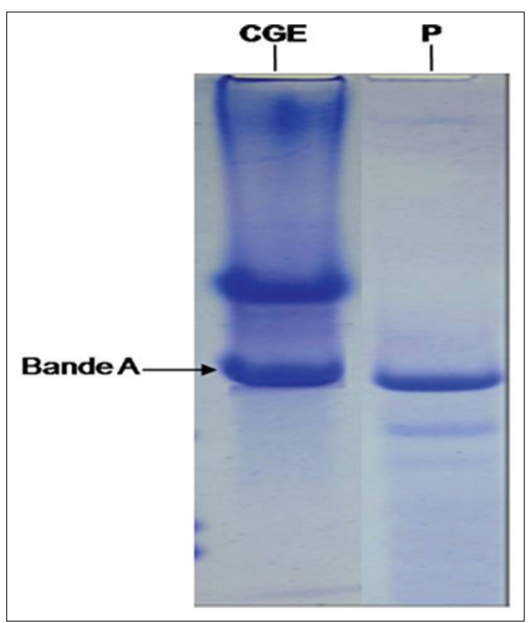

Fig 4. Native PAGE (12\%) profile of the CGE W. CGE: the crude gastric extract, $P$ : porcine pepsin.

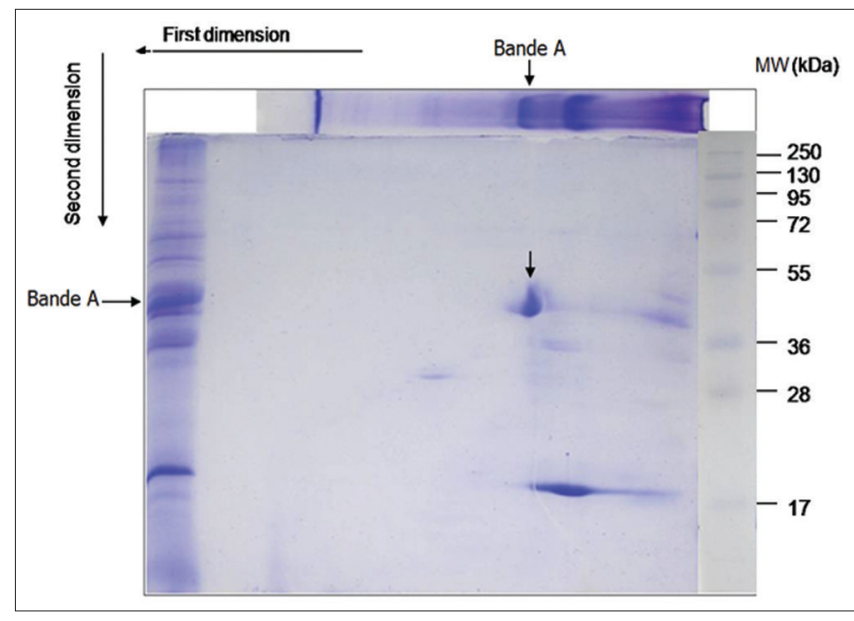

Fig 5. The two-dimensional electrophoresis of the CGE W. First dimension: Native PAGE, second dimension: SDS-PAGE. MW: Molecular weight.

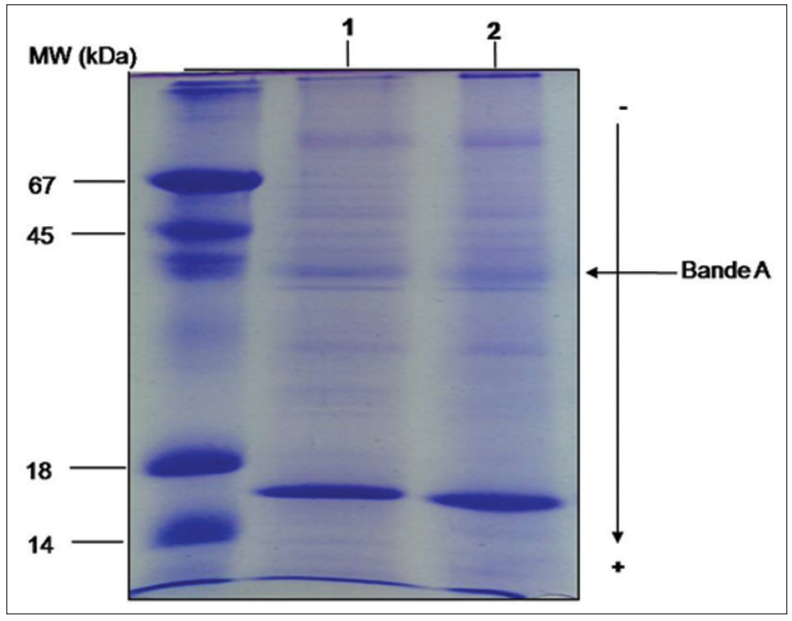

Fig 6. SDS-PAGE (17\%) profile of the CGE W.

1: With $\beta$ mercapto ethanol, 2: Without $\beta$ mercapto ethanol. MW: Molecular weight. 
Its globular structure allows it to focus on a narrow band on the gel which consists of a single peptide chain of 327 amino acid residues $(34,600 \mathrm{Da})$ (Tang et al., 1973).

\section{CONCLUSIONS}

The present study proves that there would be, at least, two active fractions in the adult camel abomasal. One milk clotting enzyme representing the highest activity which would be likely a pepsin was isolated. According to our previous results and from litterature we demonstrated that the corresponding enzyme was an acid protease $(\mathrm{p} I$ below 5.5) with molecular weight of about $38 \mathrm{kDa}$. The presence of other zymogens is not excluded. However, further experiments are needed to understand the molecular mechanism of action of this particular enzyme in camel. Indeed, it would explore the structure/function relationship of the enzyme and the rearrangements that might limite its proteolytic activity and its potential in producing camel cheese.

\section{ACKNOWLEDGEMENTS}

The authors are grateful to Ouargla Kassdi Merbah University, Algeria, for providing raw materials.

\section{Author contributions}

All authors contributed equally to this work. Isselnane S. and SI Ahmed-Zennia S. designed and performed experiments. Boudjenah-Haroun S. collected, selected and prepared the camel abomasums. Isselnane $S$. and Bouazza B. wrote the manuscript. Nouani A. and Yabrir B. revised the manuscript critically. MATI A. supervised the study. All authors analysed and interpreted the results and implications and commented on the manuscript at all stages.

\section{REFERENCES}

Abuharfeel, N. M. and G. M. Abuereish. 1984. Isolation and characterization of camel pepsins. Comp. Biochem. Physiol. A. 77(11): 175-182.

Al-Mzaien, K. A. 2007. Extraction, purification and characterization of camels pepsin (Camelus dromedarius). Iraqi. J. Biotechnol. 6(2): 64-76.

Berridge, N. J. 1945. The purificaiton and crystallization of rennin. Biochem. J. 39: 179-187.

Bornaz, S., A. Sahli, A. Attalah and H. Attia. 2009. Physicochemical characteristics and renneting properties of camels' milk: A comparison with goats', ewes' and cows' milks. Int. J. Dairy Technol. 62(4): 505-513.

Boudjenah-Haroun, S., C. L. Laleye, F. Moulti-Mati, S. Si Ahmed, N. Mahboub, O. Siboukeur and A. Mati. 2011. Comparative study of milk clotting activity of crude gastric enzymes extrated from camels' abomasum at different ages and commercial enzymes (rennet and pepsin) on bovine and camel milk. Emirates J. Food Agric. 23(4): 301-310.

Boudjenah-Haroun, S., C. L. Laleye, L. Codjo, C. Senoussi, F. MoultiMati, S. Si Ahmed and A. Mati. 2012. Coagulation of camel milk using dromedary gastric enzymes as a substitute of the commercial rennet. Am. J. Food Technol. 7: 409-419.

Chaoui-Kherouatou, N. and H. Attia. 2008. Étude comparative des caséines camelines (Camelus dromedarius) et bovines. Sci. Technol. 28: 73-79.

Chapman, M. J. 1985. Mongolian baktrian camels. World Anim. Rev. 55: 14-19.

Collin, J. C., R. Grappin and Y. Legreat. 1977. Etude de la méthode de mesure, selon Berridge, du temps de coagulation du lait additionné d'une solution enzymatique. Rev. Laitière Française. 355: 389-394.

El-Abassy, F. and H. Wahba. 1986. Studies on camel pepsin 2-manufacture of Domiati cheese with camel pepsin. Egyptian J. Dairy Sci. 14: 187-796.

El-Agamy, E. I. 2000. Physicochemical, molecular and immunological characterization of camel calf rennet: A comparison with buffalo rennet. J. Dairy Res. 67: 73-81.

El-Agamy, E. I. and N.M. Kamal. 1998. Studies on camel rennet. I. Preparation, storage stability, clotting ability and proteolytic activity. J. Agric. Sci. 23: 3861-3868.

El-Batawy, M. A., S. N. Amer and S.A. Ibrahim. 1987. Camel abomasum as a source of rennet substitute. Egypt. J.Dairy Sci. 15: 93-100.

Esumi, H., S. Sato, T. Sugimura and C. Furihata. 1978. Purification of mouse pepsinogens by pepstatin-affinity chromatography. FEBS.Lett. 86: 33-36.

Farah, Z. 1993. Composition and characteristics of camel milk. J. Dairy. Res. 60: 603-626.

Farah, Z. and M. R. Bachmann. 1987. Rennet coagulation properties of camel milk. Milchwissenschaft. 42: 689-692.

Farah, Z., and M. W. Ruegg. 1989. The size distribution of casein micelles in camel milk. Food Microstruct. 8(8): 211-216.

Foltmann, B., A. L. Jensen, P.Lanblad, E.Smidt and N.H. Axelsen. 1981. A developmental analysis of the production of chymosin and pepsin in pigs. Comp. Biochem. Physiol. 68: 9-13.

Fox, P. F., J. R. Whitaker and P. A. O'Leary. 1977. Isolation and characterization of sheep pepsin. Biochem. J. 161: 389-398.

Herian, K. and Z. Krcal. 1971. Suitability of lambs' stomachs for industrial manufacture of rennet. Prumyst-Potravin. 22(5): 137-139.

Hillier, R. M. 1976. The quantitative measurement of whey proteins using polyacrylamide gel electrophoresis.J. Dairy Res. 43: 259265.

Houen, G., M. T. Madsen, K. W. Harlow, P. Lonblad and B. Foltmann. 1996. The primary structure and enzymatic properties of porcine prochymosin and chymosin. Int. J. Biochem. Cell. Biol. 28: 667675.

Kageyama, T. and K. Takahashi. 1976. Pepsinogens and pepsins from gastric mucosa of Japanese monkey. Purification and characterization. J. Biochem. 79: 455-468.

Kappeler, S., Z. Farah and Z. Puhan. 1998. Sequence analysis of Camelus dromedarius milk caseins. J. Dairy Res. 65: 206-222.

Konuspayeva, G., Camier, B., Gaucheron, F., Faye, B. 2014. Some parameters to process camel milk into cheese. Emir. J. Food Agric., 26(4): 354-358.

Laemmli, U. K. and H. Favre. 1973. Maturation of the head of 
bacteriophage T4. I. DNA packaging events. J. Mol. Biol. 780: 575-599.

Lowry, O. H., N. J. Rosebrough, A.L. Farr and R.J. Randall. 1951. Protein measurement with Folin phenol reagent. J. Biochem. 193: 265-275.

Martin, P. 1984. Hydrolysis of the synthetic chromophoric hexapeptide Leu-Ser-Phe(NO2)-Nle-Ala-Leu-Ome catalyzed by bovine pepsin A. Biochim. Biophys.Acta. 791: 28-36.

Mehaia, M. A., M. A. Hablas, K. M. Abdel-Rahman and S. A. ElMougy. 1995. Milk composition of Majaheim, Wadah and Hamra camels in Saudi Arabia. Food Chem. 52: 115-122.

Rajagopalan, T. C., S. Moore and W. H. Stein. 1966. Pepsin from pepsinogen: Preparation and properties. J. Biol. Chem. 241: 4940-4950.

Ramet, J. P. 1985. Study of Enzymatic Coagulation of Camel Milk in Saudia-Arabia. Mission Report, FAO, Pp. 1-73.

Ramet, J. P. 1989. L'aptitude fromagère du lait de dromadaire. Rev. Élev. Méd. Véf. Pays Trop. 42(1): 105-111.

Ramet, J. P. 2003. Aptitude à la conservation et à la transformation fromagère du lait de chamelle. Actes de l'Atelier International
Sur: "Lait de chamelle pour l'Afrique", 5-8 Novembre, Niamey, Niger.

Rao, M. B., R. C. Gupta and N. N. Dastur. 1970. Camel milk and milk products. Indian J. Dairy Sci. 23(2): 71-78.

Rothe, G. A. L., N. H. Axelsen, P. Johnle and B. Foltmann. 1976. Immunochemical, chromatographic, and milk-clotting activity measurements for quantification of milk-clotting enzymes in bovine rennet's. J. Dairy Res. 43: 85-95.

Suzuki, M., Y. Narita, S. Oda, A. Moriyama and O. Takenaka. 1999. Purification and characterization of goat pepsinogens and pepsins. Comp. Biochem. Physiol. B. Biochem. Mol. Biol. 122: 453-460.

Tang, J., P. Sepulveda, J. Marciniszyn, K. C. S. Chen, W. Y. Huang, N. Tao, D. Liu and J. P. Lanier. 1973. Amino-acid sequence of porcine pepsin. Proc. Natl. Acad. Sci. USA. 70: 3437-3439.

Valles, E. and J. P. Furet. 1977. Etude des caillettes des bovins à l'état ruminant pour l'obtention des extraits coagulants à base de pepsine bovine; Méthodes d'extraction. Lait. 61: 601-617.

Wangoh, J., Z. Farah and Puhan, Z. 1993. Extraction of camel rennet and its comparison with calf rennet extract. Milchwissenschaft. 48: 322-325. 